\title{
U.S. Civil Rights and the Power of the Press
}

\section{Clarence W Thomas*}

School of Mass Communications, Virginia Commonwealth University, USA

During the 1950s and 1960s, America underwent a major transition in racial attitude, tradition, and policy. The people, organizations, and events--collectively the civil rights movement--which initiated the transition were presented to America and the world by the press. During this time, some segments of the American press came to be thought of as allies of the movement and facilitators of movement objectives.

Civil rights leaders, journalists who covered the movement, social scientists, and historians generally agree that the press did not start the civil rights movement. However, they do contend that the movement would have taken longer to achieve many of its goals or would not have succeeded at all if not for press interest and coverage.

Press interest in and coverage of the civil rights movement and the movement's need and use of the press led to a mutually beneficial relationship. That relationship provided the press with one of the most important stories of the century as well as the opportunity to stimulate a self-correcting capacity (discussed later) within American society. Similarly, the relationship facilitated the movement by providing the impetus for the popular and governmental support needed as a basis for social change--in this case civil rights for black Americans.
${ }^{*}$ Corresponding author: Clarence W. Thomas, Associate Professor, School of Mass Communications, Virginia Commonwealth University, USA, Tel: 804-827-3772; E-mail: cwthomas@vcu.edu

Received May 09, 2013; Accepted May 10, 2013; Published May 15, 2013

Citation: Thomas CW (2013) U.S. Civil Rights and the Power of the Press. J Mass Communicat Journalism 3: e134. doi:10.4172/2165-7912.1000e134

Copyright: (c) 2013 Thomas CW. This is an open-access article distributed under the terms of the Creative Commons Attribution License, which permits unrestricted use, distribution, and reproduction in any medium, provided the original author and source are credited. 